\title{
Postępowanie chirurgiczne w przypadku nawrotu miejscowego po leczeniu oszczędzającym raka piersi — mastektomia czy ponowne miejscowe wycięcie?
}

\author{
Wojciech M. Wysocki, Krzysztof Herman
}

\begin{abstract}
Wstęp. Całkowite ryzyko nawrotu miejscowego w obrębie piersi (IBRT) po leczeniu oszczędzającym przeprowadzonym u chorych na raka piersi mieści się w szerokim zakresie 2-35\%. W takiej sytuacji klinicznej zalecane postępowanie polega na mastektomii prostej. Jednakże w ostatnich latach udostępniono dane, które pozwalają sądzić, że ta zasada ulegnie wkrótce zmianie.
\end{abstract}

Materiał i metody. Do analizy włączono artykuły odszukane w bazie Pubmed za okres 1990-2013, dotyczące postępowania z IBTR u chorych na niezaawansowanego raka piersi, operowanych sposobem oszczędzającym. W analizie uwzględniono wyłącznie wybrane artykuły opublikowane w języku angielskim lub niemieckim.

Wyniki. Ryzyko rozwoju IBRT po leczeniu oszczędzającym u chorych na raka piersi w ciągu minionych 3 dekad ulegało systematycznemu zmniejszaniu: od wartości sięgającej kilkunastu do kilku procent. Miejscowe wycięcie IBRT nie wiąże się z większym ryzykiem wystąpienia kolejnego, drugiego IBRT w porównaniu z mastektomią prostą „ratunkową" (7-32\% w porównaniu z 4-32\%). Wyniki miejscowego wycięcia IBRT z użyciem powtórnego napromieniania są obiecujące - w badaniach przeprowadzonych w ostatnich latach ryzyko drugiego IBRT w tej grupie chorych waha się od 0 do 3\% i nie odbiega od ryzyka pierwszego IBRT po współczesnym leczeniu oszczędzającym.

Podsumowanie. Przegląd piśmiennictwa wskazuje, że w praktyce klinicznej w przypadku nawrotu miejscowego po leczeniu oszczędzającym pierś stosuje się — oprócz rekomendowanej mastektomii prostej — także ponowne miejscowe wycięcie IBRT. W ostatnich latach coraz częściej postępowanie takie uzupełnia się powtórną radioterapią. Ryzyko kolejnego IBRT po zastosowaniu takiego postępowania nie jest większe niż ryzyko nawrotu miejscowego obserwowane po mastektomii, ratunkowej”. Przydatność ponownego leczenia miejscowego wydaje się być szczególnie uzasadniona u chorych z małym ogniskiem, z późnym nawrotem i z silną ekspresją receptorów estrogenowych w obrębie wznowy. Aby w pełni ocenić wartość miejscowego wycięcia IBRT po leczeniu oszczędzającym pierś, należy oczekiwać na wyniki odpowiednio zaprojektowanych porównawczych badań prospektywnych.

\section{Surgical management of ipsilateral breast tumour recurrence after breast conserving therapy: mastectomy or further local excision?}

Introduction. The overall risk of ipsilateral breast tumour recurrence (IBRT) following breast conserving therapy (BCT) ranges from $2 \%$ to $35 \%$. Total mastectomy is uniformly recommend for IBRT following BCT. However evidence released recently suggests that there may be a change in clinical practice in the near future.

Material and methods. The Pubmed database for 1990-2013 was searched and we included articles on IBRT for early breast cancer patients after breast conserving therapy. Only selected articles, published in English or German, were reviewed.

Results. The risk of IBRT after BCT in the last three decades gradually decreased from 10-15\% to a few percent. Local excision of IBRT is not associated with higher risk of second local recurrence, when compared to "salvage" total ma- 
stectomy (7-32\% vs 4-32\%). Local excision of IBRT with re-irradiation brings promising results. In recent studies the risk of a second IBRT in re-excised and re-irradiated cases ranged from $0 \%$ to $3 \%$ and is this not worse when compared to the currently reported risk of first IBRT following breast conservation.

Conclusions. This review shows that clinical practice is to perform (apart from widely recommended total mastectomy) also local excision of IBRT following BCT. In recent years re-irradiation is more commonly used. The risk of second IBRT does not seem to be higher than the local recurrence risk following "salvage" total mastectomy. Local excision of IBRT appears to be particularly promising in small, late and hormonal receptors showing positive IBRT. Treatment for IBRT needs to be verified in properly designed prospective comparative studies.

NOWOTWORY Journal of Oncology 2014; 64, 2: 163-168

Słowa kluczowe: rak piersi, leczenie oszczędzające, nawrót miejscowy, leczenie operacyjne

Key words: breast cancer, breast conservation, local recurrence, surgical management

\section{Wprowadzenie}

Zmniejszenie prawdopodobieństwa wystąpienia nawrotu miejscowego (IBRT —ipsilateral breast tumor recurrence) po leczeniu oszczędzającym (BCT) u chorych na raka piersi stanowi jeden z głównych celów postępowania terapeutycznego. Podawane w piśmiennictwie całkowite ryzyko IBRT mieści się obecnie w szerokim przedziale od około $2 \%$ do $35 \%$. U około 1/3 chorych jednocześnie z nawrotem miejscowym dochodzi do nawrotu systemowego [1]. Panuje przekonanie, że w aspekcie ryzyka nawrotu miejscowego leczenie oszczędzające ustępuje mastektomii [2, 3]. Ryzyko IBRT po leczeniu oszczędzającym jest większe niż ryzyko nawrotu miejscowego po mastektomii (w badaniu mediolańskim [2] odpowiednio 8,8\% i 2,3\%). Jednakże całkowity odsetek przeżyć chorych na niezaawansowanego raka piersi, operowanych z intencją oszczędzenia gruczołu, nie jest gorszy niż ten wskaźnik w grupie kobiet poddawanych amputacji piersi — nawet w kilkudziesięcioletniej obserwacji [2, 3].

Od lat 70. ubiegłego wieku, to jest od czasu rozpoczęcia stosowania leczenia oszczędzającego pierś, przyjęto, że w razie IBRT leczeniem z wyboru winna być amputacja piersi. Pogląd ten jest wciąż podtrzymywany przez większość aktualnych rekomendacji światowych oraz polskich towarzystw i organizacji onkologicznych [4-6].

W ostatnich latach zaprezentowano nowe dane, na podstawie których można sądzić, że stosowane dotychczas standardowe postępowanie u chorych, u których doszło do IBTR po leczeniu oszczędzającym pierś, może w przyszłości ulec zmianie. Celem niniejszego artykułu jest omówienie wybranych danych na ten temat i określenie prawdopodobnego kierunku zmian w postępowaniu terapeutycznym w przypadku IBRT po leczeniu oszczędzającym pierś.

\section{Materiał i metoda}

Do analizy włączono wybrane artykuły z bazy Pubmed w przedziale lat 1990-2013, dotyczące postępowania z IBTR u chorych na niezaawansowanego raka piersi, operowanych sposobem oszczędzającym. W analizie uwzględniono wyłącznie artykuły opublikowane w języku angielskim lub niemieckim. Przegląd piśmiennictwa nie ma charakteru systematycznego ${ }^{1}$. Odszukane dane źródłowe odznaczają się dużą heterogenicznością definicji IBRT (kryterium lokalizacji w loży guza lub do 2-3 cm od loży albo brak jakiegokolwiek kryterium poza umiejscowieniem wznowy w tej samej piersi), stosowanych metod leczenia (zakresu operacji, technik radioterapii, podejmowanego leczenia systemowego) oraz sposobów prezentacji wyników (nawroty miejscowe, nawroty lokoregionalne, odmienne okresy obserwacji itp.).

W niniejszym artykule ograniczono się wyłącznie do analizy postępowania chirurgicznego w przypadku IBRT po wcześniejszym leczeniu oszczędzającym. Nie analizowano postępowania w przypadku nawrotów w obrębie dołu pachowego.

\section{Omówienie \\ Ryzyko wystąpienia IBRT}

Rzeczywiste ryzyko wystąpienia IBRT prezentowane w piśmiennictwie jest - wbrew pozorom - trudne do oceny z uwagi na zróżnicowany sposób raportowania tego parametru w dostępnych badaniach (łączenie nawrotów miejscowych i lokoregionalnych, podawanie zbiorczego [kumulacyjnego] ryzyka nawrotu dla różnych okresów obserwacji [5, 10 lub 20 lat], łączne traktowanie rzeczywistego nawrotu miejscowego i noworozwijającego się raka w tej samej piersi, raportowanie nawrotu miejscowego jako jedynej cechy niepowodzenia leczenia [tj. bez ewentualnego towarzyszącego nawrotu systemowego] itp.). Wydaje się, że największym problemem jest brak jednoznacznych kryteriów oceniających, czy mamy do czynienia z rzeczywistą wznową miejscową usuniętego nowotworu czy teżz nowym nowotworem. Czy podejrzane ognisko, które pojawiło się

\footnotetext{
'Ostatecznego doboru danych do prezentacji przygotowywanej na Zjazd Polskiego Towarzystwa Chirurgii Onkologicznej w Gdańsku (23-25 maja 2013 r.) oraz do opartego na tej prezentacji niniejszego artykułu dokonano po dyskusji w gronie autorów.
} 
rok po zabiegu i jest położone $5 \mathrm{~cm}$ od blizny, jest nawrotem? Czy inne podejrzane ognisko, które się pojawiło 5 lat po zabiegu, ale jest położone tylko $1 \mathrm{~cm}$ od blizny, jest nowym nowotworem? Czy ognisko IBTR z rakiem przedinwazyjnym nie jest traktowane jako nawrót raka inwazyjnego współistniejącego z rakiem przedinwazyjnym?

W pionierskim badaniu Fishera i wsp., obejmującym lata 1976-1984, w którym leczenie oszczędzające (wycięcie guza oraz uzupełniającą radioterapię) zastosowano u 628 kobiet, odsetek IBTR wynosił 14,3\% (mediana okresu obserwacji 20 lat) [3]. W toczącym się równolegle badaniu Veronesiego i wsp. (lata 1973-1980) wśród 352 kobiet poddanych szerokiemu wycięciu guza i uzupełniającej radioterapii odsetek IBRT wynosił 8,8\% (mediana okresu obserwacji wynosiła 20 lat). Odsetek ten był większy, niż obserwowany odsetek nawrotów miejscowych po mastektomii (2,3\%) [2]. W dużym badaniu pochodzącym z lat 1984-1997 (352 kobiety poddane szerokiemu wycięcia guza i uzupełniającej radioterapii; mediana okresu obserwacji 100 miesięcy) odsetek IBRT wynosił 5,4\% [7]. Z kolei w badaniu opublikowanym w roku 2012 odsetek IBTR (grupa > 12000 kobiet poddanych leczeniu oszczędzającemu w latach 1997-2004, okres obserwacji > 5 lat) był istotnie mniejszy niż w poprzednich dekadach i sięgał 2,5\% [8].

Przedstawione dane wskazują, że ryzyko rozwoju IBRT po leczeniu oszczędzającym chorych na raka piersi w ciągu minionych 3 dekad ulegało systematycznemu zmniejszaniu: od wartości sięgającej kilkunastu do kilku procent. Należy tu zastrzec, że poprawa pod względem analizowanego parametru jest efektem rozwoju radioterapii (w tym wprowadzenia techniki dopromieniania boost) oraz diagnostyki obrazowej (pozwalającej na wczesne wykrywanie bardzo małych ognisk raka). Udział chirurgii w poprawie wyników w omawianym zakresie jest prawdopodobnie najmniejszy, jednak różne metodologie omawianych prac uniemożliwiają wyciągnięcie bardziej jednoznacznych wniosków w tym względzie.

Systematyczne zmniejszenie ryzyka IBRT w minionych dekadach znajduje odbicie w wysokości rekomendowanych współcześnie progów definiujących odpowiednią jakość leczenia oszczędzającego pierś. Aktualne zalecenia British Association of Surgical Oncology (BASO) wskazują, że: „We wszystkich przypadkach raka naciekającego, zakwalifikowanych do leczenia oszczędzającego, ryzyko nawrotu miejscowego w ciągu 5 lat od zakończenia leczenia musi wynosić $<5 \%$ (docelowo < 3\%)" [9].

\section{Aktualne zalecenia dotyczq̨ce postępowania w przypadku IBRT}

Aktualne zalecenia organizacji i stowarzyszeń onkologicznych są zgodne. W przypadku IBRT European Society for Medical Oncology (ESMO) w rekomendacjach z 2012 r. (nieaktualizowanych w 2013 r.) zaleca wykonanie mastek- tomii i ewentualnie „rzekomo uzupełniającą" hormono- lub chemioterapię. W rekomendacjach ESMO autorzy zastrzegają jednak, że zalecenie powyższe opiera się na danych pochodzących z badań o niedoskonałej metodologii i bez randomizacji [6]. Północnoamerykańska National Comprehensive Cancer Network w dokumencie pochodzącym z pierwszego kwartału 2013 roku w przypadku IBRT po leczeniu oszczędzającym jednoznacznie zaleca mastektomię prostą (wraz z odpowiednim postępowaniem uzupełniającym) [5]. Także polskie rekomendacje opracowane przez Polskie Towarzystwo Onkologii Klinicznej i opublikowane w 2013 r. nie odbiegają w tym zakresie od przytoczonych wyżej dokumentów, wskazując na mastektomię prostą jako na postępowanie $z$ wyboru [4].

Z drugiej strony opublikowane wiosną 2013 roku niemieckie zalecenia Arbeitsgemeinschaft Gynäkolgische Onkologie (AGO) wskazują na możliwość podjęcia ponownej próby leczenia oszczędzającego po wystąpieniu pierwszego IBRT (postępowanie takie obwarowane jest jednak licznymi zastrzeżeniami, a siła tego zalecenia jest istotnie słabsza niż siła przesłanek do rekomendowania mastektomii prostej) [10].

\section{Dlaczego zaleca się mastektomię?}

Dlaczego aktualne rekomendacje kliniczne zgodnie wskazują na mastektomię prostą jako sposób z wyboru leczenia IBRT po leczeniu oszczędzającym? Argumenty przemawiające za takim postępowaniem podsumowała Suarez i wsp. w 2011 r.:, 1) nawrót miejscowy po ponownym leczeniu oszczędzającym bez ponownej radioterapii dotyczy nawet $50 \%$ chorych, 2) ponowne wycięcie miejscowe może wiązać się z niemożliwym do zaakceptowania efektem estetycznym operacji oraz 3) ponowne napromienianie piersi uważano za niewłaściwe z uwagi na prawdopodobieństwo znacznego uszkodzenia tkanek" [11].

Wydaje się jednak, że pojawiły się nowe dane, które pozwolą w przyszłości na zmianę obowiązujących zaleceń klinicznych [10]. Wymienione przez Suarez i wsp. trzy główne argumenty przemawiające za mastektomią „ratunkową" można obecnie podważać ponieważ: 1) dane z piśmiennictwa z ostatnich 2-4 lat wskazują, że ryzyko drugiego IBRT jest co najmniej o 2/3 mniejsze, niż wskazuje Suarez [12], 2) efekt estetyczny można istotnie poprawić, stosując popularne obecnie metody onkoplastyczne, 3) współczesna technika radioterapeutyczna coraz częściej umożliwia bezpieczne i skuteczne przeprowadzenie ponownego napromieniania.

\section{Przesłanki do zmiany standardu}

Oceniając przesłanki do zmiany standardowego postępowania w przypadku IBRT, należy ocenić ryzyko wystąpienia kolejnego nawrotu miejscowego. W 2013 r. Hannoun-Levi i wsp. przedstawili zestawienie dostępnych danych na ten temat, wskazując, że prawdopodobieństwo wystąpienia ponownego nawrotu miejscowego po „ratunkowej” ma- 
Tabela I. Porównanie ryzyka wystąpienia drugiego nawrotu miejscowego po miejscowym wycięciu pierwszego nawrotu miejscowego w grupie z zastosowaniem i bez zastosowania powtórnej radioterapii

\begin{tabular}{|c|c|c|c|}
\hline \multicolumn{2}{|c|}{$\begin{array}{c}\text { Chore poddane miejscowemu wycięciu IBRT } \\
\text { bez powtórnego napromieniania }\end{array}$} & \multicolumn{2}{|c|}{$\begin{array}{c}\text { Chore poddane miejscowemu wycięciu IBRT } \\
\text { z powtórnym napromieniania }\end{array}$} \\
\hline Autor & Ponowny IBRT & Autor & Ponowny IBRT \\
\hline Kurtz i wsp. (1991) [10] & $27 \%$ & Deutsch i wsp. (2002) [24] & $20 \%$ \\
\hline Abner i wsp. (1993) [20] & $31 \%$ & Resch i wsp. (2002) [25] & $24 \%$ \\
\hline Dalberg i wsp. (1998) [21] & $50 \%$ & Kraus-Tiefenbacher i wsp. (2007) [26] & $0 \%$ \\
\hline Voogd i wsp. (1999) [22] & $38 \%$ & Chadha i wsp. (2008) [27] & $5,6 \%$ \\
\hline Salvadori i wsp. (1999) [14] & $19 \%$ & Trombetta i wsp. (2008) [28] & $4,7 \%$ \\
\hline Komoike i wsp. (2003) [23] & $27 \%$ & Hannoun-Levi i wsp. (2010) [29] & $3 \%$ \\
\hline \multirow[t]{2}{*}{ Alpert i wsp. (2005) [15] } & $6,6 \%$ & Guix i wsp. (2010) [13] & $2,7 \%$ \\
\hline & & Adkinson i wsp. (2010) [30] & $0 \%$ \\
\hline
\end{tabular}

stektomii wahało się w szerokim przedziale od 4 do $32 \%$. Dane te uzyskano, analizując 10 opublikowanych badań, w których opisano łącznie 1066 chorych. Dla porównania autorzy zaprezentowali także dane pochodzące z 6 artykułów, obejmujące łącznie 248 chorych, u których doszło do IBRT i u których nawrót ten wycięto miejscowo (nie stosowano ponownego napromieniania). Odsetek ponownego IBRT wynosił w tej grupie od 7 do $32 \%$ i nie odbiegał od zakresu odnotowanego u chorych poddanych mastektomii w chwili rozpoznania pierwszego IBRT (4-32\%). Hannoun-Levi i wsp. zgromadzili ponadto dane pochodzące z 10 badań — łącznie 531 chorych, którym po rozpoznaniu IBRT wycięto miejscowo ognisko nawrotu, a następnie przeprowadzono ponowne napromienianie ( $z$ użyciem technik radioterapii odpowiednich w takich warunkach klinicznych). W tej grupie chorych prawdopodobieństwo rozwoju drugiego IBRT wahało się w zakresie od 0 do 26\% [12].

Analiza wyników miejscowego wycięcia IBRT (zarówno z użyciem powtórnej radioterapii, jak i bez zastosowania tej metody), z uwzględnieniem chronologii ukazywania się odnośnych badań, wskazuje, że odsetek drugiego nawrotu miejscowego w badaniach starszych był większy niż w przypadku badań współczesnych (tab. I). W szczególności należy zwrócić uwagę na analizę Guixa i wsp. z 2010 r., w której opisano 36 chorych poddanych miejscowemu wycięciu ogniska IBRT i uzupełniającej powtórnej radioterapii (30 Gy HDR) obejmującej pierś. Mediana okresu obserwacji wynosiła 89 miesięcy, a odsetek drugiego IBRT wyniósł zaledwie 2,7\% (13) — w przybliżeniu tyle, ile wyniósł odsetek pierwotnych (!) IBRT w dużej analizie, obejmującej > 12000 kobiet leczonych z oszczędzeniem piersi [8].

Dostępne dane pozwalają stwierdzić, że miejscowe wycięcie IBRT nie wiąże się z większym ryzykiem wystąpienia kolejnego, drugiego nawrotu miejscowego w porównaniu z mastektomią,rratunkową" (7-32\% w porównaniu z 4-32\%). Wyniki miejscowego wycięcia IBRT z użyciem powtórnego napromieniania są bardzo obiecujące - w badaniach przeprowadzonych w ostatnich latach ryzyko drugiego IBRT w tej grupie chorych waha się od 0 do 3\% (tab. I) i nie odbiega od ryzyka pierwszego IBRT po leczeniu oszczędzającym [14].

Dodatkowym argumentem przemawiającym za odstąpieniem od dogmatu standardowego leczenia chorych z IBRT za pomocą mastektomii "ratunkowej” jest fakt, że w głównych historycznych badaniach dotyczących leczenia oszczędzającego pierś de facto stosowano ponowne miejscowe wycięcie IBRT. Na przykład w badaniu Veronesiego i wsp. [2] u 3,3\% chorych, u których doszło do IBRT, zamiast zalecanej mastektomii „ratunkowej” wykonano ponowne miejscowe wycięcie IBRT. W badaniu nieco bardziej współczesnym, obejmującym lata 90. XX wieku (okres obserwacji wynosił 10 lat), łącznie u 17,1\% chorych zamiast mastektomii prostej z powodu IBRT po leczeniu oszczędzającym pierś podjęto próbę kolejnego miejscowego wycięcia IBRT [7].

Analizując efektywność ponownego miejscowego wycięcia pierwszego IBRT, należy uwzględnić najważniejszy parametr opisujący skuteczność leczenia przeciwnowotworowego - odsetek osób przeżywających $\geq 5$ lat. W 1999 roku ukazała się analiza losów 2544 chorych poddanych leczeniu oszczędzającemu; wśród nich u 209 doszło do izolowanego IBRT. Odsetek osób przeżywających 5 lat wśród poddanych mastektomii ratunkowej wynosił 70\%, znacząco mniej niż wśród poddanych wycięciu miejscowemu ogniska IBRT — 85\% [14]. W 2005 r. przedstawiono wyniki leczenia 146 chorych, u których doszło do IBRT — po leczeniu oszczędzającym: 116 chorych poddano mastektomii, „ratunkowej”, a 30 wycięciu miejscowemu. Odsetek osób przeżywających 10 lat w obu grupach nie różnił się znamiennie i wyniósł odpowiednio $65,7 \%$ i 58,0\% [15].

Badanie Chena i wsp. przyniosło częściowo przeciwne wyniki. Na podstawie analizy losów 747 chorych leczonych chirurgicznie z powodu IBRT w latach 1988-2004, których dane były dostępne w bazie Surveillance, Epidemiology, and End Results (SEER), stwierdzono, że odsetek osób przeżywających 5 lat był znamiennie gorszy u osób poddanych miejscowemu wycięciu IBRT w porównaniu z mastektomią "ratunkową" (67\% w porównaniu z 78\%, $p=0,03)$. Jednak- 
że w dłuższej obserwacji (10 lat) różnica pomiędzy grupami zmniejszała się (odpowiednio 62\% i 57\%). Co więcej, po ograniczeniu analizy do guzów pierwotnych, których średnica nie przekraczała $2 \mathrm{~cm}(\mathrm{~T} 1)$, różnica stawała się nieznamienna. Ponadto ponowną radioterapię stosowano tylko u $21 \%$ wszystkich chorych poddanych miejscowemu wycięciu IBRT [16], dlatego, mimo niekorzystnego wyniku w zakresie całkowitego odsetka osób przeżywających 5 lat, badanie Chena i wsp. nie może być używane jako kategoryczny argument przeciwko miejscowemu wycięciu IBRT.

Niestety brak jest prospektywnych badań klinicznych z randomizacją porównujących obie metody leczenia nawrotu miejscowego. Pomimo pewnych trudności metodologicznych mogłyby one dać lepszą wykładnię odnośnie prawidłowego postępowania w tych przypadkach.

W kontekście ryzyka nawrotu miejscowego po leczeniu chorych na raka piersi, które według rekomendacji uznanych towarzystw [9] nie powinno obecnie przekraczać 5\%, należy zwrócić uwagę na artykuł pochodzący z 1896 roku. W artykule tym William S. Halsted podsumował wyniki dwuletniej obserwacji 50 chorych na raka piersi, operowanych opracowaną przez siebie metodą. Odsetek nawrotów miejscowych odnotowanych przez Halsteda wynosił 6,6\% [17]. Trzeba podkreślić, że przeszło 110 lat później ryzyko nawrotu miejscowego - mimo znacznego zmniejszenia rozległości operacji i wprowadzenia terapii uzupełniającej — wciąż jest niewiele mniejsze niż wówczas.

\section{Kryteria doboru do miejscowego wycięcia IBRT}

W 2012 r. przedstawiono wyniki wieloletniej obserwacji 12357 chorych poddanych leczeniu oszczędzającemu pierś w ośrodku mediolańskim. Całkowity odsetek IBRT wyniósł 2,5\%. U około połowy chorych z IBRT leczenie nawrotu polegało na ponownym miejscowym wycięciu bez ponownej radioterapii. Po okresie obserwacji, którego mediana wynosiła 44 miesiące, częstość kolejnego IBRT wynosiła 27\% [8]. Gentilli i wsp. podjęli próbę identyfikacji czynników zwiększających ryzyko wystąpienia kolejnego IBRT po miejscowym wycięciu pierwszej IBRT, ustalając, że ryzyko to jest znamiennie większe w przypadku, gdy średnica nawrotu wynosiła $>2 \mathrm{~cm}$, a nawrót następował w czasie krótszym niż 48 miesięcy od pierwotnej operacji [8]. Inni autorzy zwrócili uwagę na te same czynniki [15], a dodatkowo również na korzystniejsze wyniki u chorych, u których w obrębie wznowy stwierdzano silną ekspresję receptorów estrogenowych [18].

\section{Wnioski}

Dokonany przegląd piśmiennictwa wskazuje, że mimo zgodnych rekomendacji towarzystw naukowych od wielu lat w praktyce klinicznej w przypadku nawrotu miejscowego po leczeniu oszczędzającym pierś stosuje się — oprócz mastektomii - także ponowne miejscowe wycięcie IBRT. W ostatnich latach coraz częściej postępowanie takie uzu- pełnia się powtórną radioterapią. Ryzyko kolejnego nawrotu miejscowego po zastosowaniu takiego postępowania nie jest większe niż obserwowane po mastektomii „,ratunkowej”. Przydatność ponownego leczenia miejscowego wydaje się być szczególnie uzasadniona u chorych z małym ogniskiem, z późnym nawrotem i z silną ekspresją receptorów estrogenowych w obrębie wznowy. Jednakże aby w pełni ocenić wartość miejscowego wycięcia IBRT po leczeniu oszczędzającym pierś, należy oczekiwać na wyniki odpowiednio zaprojektowanych porównawczych badań prospektywnych.

\section{Konflikt interesu: nie zgłoszono}

\section{Dr med. Wojciech M. Wysocki}

Klinika Chirurgii Onkologicznej

Centrum Onkologii Oddział w Krakowie

ul. Garncarska 11, 31-115 Kraków

e-mail:z5wysock@cyf-kr.edu.pl

Otrzymano: 20 sierpnia $2013 r$

Przyjęto do druku: 3 września 2013 r.

\section{Piśmiennictwo}

1. Küchenmeister U, Kuhnt T, Knauerhase H i wsp. Indikationen zur Strahlentherapie beim lokal rezidivierten Mammakarzinom. Der Onkologe. 2013; 19: 481-486.

2. Veronesi U, Cascinelli N, Mariani L i wsp. Twenty-year follow-up of a randomized study comparing breast-conserving surgery with radical mastectomy for early breast cancer. N Engl J Med 2002; 347: 1227-1232.

3. Fisher B, Anderson S, Bryant Ji wsp. Twenty-year follow-up of a randomized trial comparing total mastectomy, lumpectomy, and lumpectomy plus irradiation for the treatment of invasive breast cancer. NEngl J Med 2002; 347: 1233-1241.

4. Jassem J, Krzakowski M (red.). Rak piersi. W: Krzakowski M, Warzocha K (red.).Zalecenia postepowania diagnostyczno-terapeutycznego wnowotworach złośliwych - 2013. Gdańsk: Via Medica; 211-263.

5. National Comprehensive Cancer Network Clinical Cancer Guidelines in Oncology. Breast Cancer v.2.2013. www.nccn.org. Dostęp online 4/5/2013.

6. F. Cardoso, Harbeck N, Fallowfield L i wsp. on behalf of the ESMO Guidelines Working Group. Locally recurrent or metastatic breast cancer: ESMO Clinical Practice Guidelines for diagnosis, treatment and follow-up. Ann Oncol 2012; 23 (Supp. 7): vii11-vii19.

7. Hammer J,TrackC, Seewald DHiwsp.Local relapse after breast-conserving surgery and radiotherapy: effects on survival parameters. Strahlenther Onkol 2009; 185: 431-437.

8. Gentilini O, Botteri E, Veronesi P i wsp...Repeating conservative surgery after ipsilateral breast tumor reappearance: criteria for selecting the best candidates. Ann Surg Oncol 2012; 19: 3771-3776.

9. Association of Breast Surgery at British Association of Surgical Oncology 2009. Surgical guidelines for the management of breast cancer. Eur J Surg Oncol 2009; 35 (Suppl 1): S1-S22.

10. Loko-regionaeres Rezidiv. Version 2013.1D. Arbeitsgemeinschaft Gynäkolgische Onkologie e. V. in der DGGG e.V. sowie in der DKG e.V. (http://www.ago-online.de/fileadmin/downloads/leitlinien/mamma/2013_02_Februar/pdfs_D/2013D\%2018_Loko-regionaeres\%20 Rezidiv.pdf) Dostęp online 30/7/2013 r.

11. Suarez J, Arthur D, Woodward W i wsp. Breast preservation in patients with local recurrence after breast-conserving therapy. Curr Breast Cancer Rep 2011; 3: 88-96.

12. Hannoun-Levi JM, Ihrai T, Courdi A. Local treatment options for ipsilateral breast tumour recurrence Cancer Treat Rev. 2013; 39: 737-741.

13. Guix B, Lejárcegui JA, Tello Jl i wsp. Exeresis and brachytherapy as salvage treatment for local recurrence after conservative treatment for breast cancer: results of a ten-year pilot study. Int J Radiat Oncol Biol Phys 2010; 78: 804-810. 
14. Salvadori B, Marubini E, Miceli Ri wsp. Reoperation for locally recurrent breast cancer in patients previously treated with conservative surgery. Br J Surg 1999; 86: 84-87.

15. Alpert TE, Kuerer HM, Arthur DW i wsp. Ipsilateral breast tumor recurrence after breast conservation therapy: outcomes of salvage mastectomy vs. salvage breast-conserving surgery and prognostic factors for salvage breast preservation. Int J Radiation Oncolog Biol Phys 2005; 63: 845-851.

16. Chen SL, Martinez SR. The survival impact of the choice of surgical procedure after ipsilateral breast cancer recurrence. Am J Surg 2008; 196: 495-499.

17. Halsted WS. The results of operations for the cure of cancer of the breast performed at the John Hopkins Hospital from June, 1889, to January 1894. Ann Surg 1894; 497-555.

18. Ishitobi M, Komoike $Y$, Nakahara S i wsp. Repeat lumpectomy for ipsilateral breast tumor recurrence after breast-conserving treatment. Oncology. 2011; 81: 381-386.

19. Kurtz JM, Jacquemier J, Amalric R i wsp. Is breast conservation after local recurrence feasible? Eur J Cancer 1991; 27: 240-244.

20. Abner AL, Recht A, Eberlein T i wsp. Prognosis following salvage mastectomy for recurrence in the breast after conservative surgery and radiation therapy for early-stage breast cancer. J Clin Oncol 1993; 11: 44-48.

21. Dalberg K, Mattsson A, Sandelin K i wsp. Outcome of treatment for ipsilateral breast tumor recurrence in early-stage breast cancer. Breast Cancer Res Treat 1998; 49: 69-78.

22. Voogd AC, van Tienhoven G, Peterse HL i wsp. Local recurrence after breast conservation therapy for early stage breast carcinoma: detection, treatment, and outcome in 266 patients. Dutch Study Group on
Local Recurrence after Breast Conservation (BORST). Cancer 1999; 85 : 437-446.

23. Komoike Y, Motomura K, Inaji H i wsp. Repeat lumpectomy for patients with ipsilateral breast tumor recurrence after breast-conserving surgery. Oncology 2003; 64: 1-6.

24. Deutsch M. Repeat high-dose external beam irradiation for in-breast tumor recurrence after previous lumpectomy and whole breast irradiation. Int J Radiat Oncol Biol Phys 2002; 53: 687-691.

25. Resch A, Fellner C, Mock U i wsp. Locally recurrent breast cancer: pulse dose rate brachytherapy for repeat irradiation following lumpectomy - a second chance to preserve the breast. Radiology 2002; 225: 713-718.

26. Kraus-Tiefenbacher U, Bauer L, Scheda A i wsp. Intraoperative radiotherapy (IORT) is an option for patients with localized breast recurrences after previous external-beam radiotherapy. BMC Cancer 2007; 7: 178.

27. Chadha M, Felman S, Boolbol S i wsp. The feasability of a second lumpectomy and breast brachytherapy for localized cancer in a breast previously treated with lumpectomy and radiation therapy for breast cancer. Brachytherapy 2008; 7: 22-28.

28. Trombetta M, Julian T, Bhandari T i wsp. Breast conservation surgery and interstitial brachytherapy in the management of locally recurrent carcinoma of the breast: the Allegheny General Hospital experience. Brachytherapy 2008; 7: 29-36.

29. Hannoun-Levi JM, Castelli J, Plesu A i wsp. Second conservative treatment for ipsilateral breast cancer recurrence using high-dose rate interstitial brachytherapy: Preliminary clinical results and evaluation of patient satisfaction. Brachytherapy 2011; 10: 171-177.

30. Adkinson JB, Kuske RR, Patel R. Breast conserving surgery and accelerated partial breast irradiation after prior breast radiation therapy. Am J Clin Oncol 2010; 33: 427-431.

W dniach 5-7 września 2014 r. odbędzie się w Ustce

Konferencja naukowo-szkoleniową „XI Usteckie Dni Onkologiczne”

\author{
Przewodniczący Komitetu Naukowego: \\ prof. Andrzej Szawłowski \\ prof. Janusz Jaśkiewicz \\ Przewodniczący Komitetu Organizacyjnego \\ dr Zoran Stojčev \\ Główne tematy: \\ — Genetyka w służbie chirurgii onkologicznej \\ - Powikłania chirurgiczne i onkologiczne leczenia nowotworów \\ —-Sesja dla pielęgniarek: Rak piersi — współczesne wyzwania i nadzieje \\ Miejsce obrad: \\ Hotel Royal Baltic, Ustka, ul. Wczasowa 26 \\ Informacje: \\ tel./fax 059/8460368, 512004399, 601490560, \\ e-mail: onkoustka@wp.pl, http://www.onko.ustka.pl
}

